\title{
Kilolu Çocuklarda Metabolik Sendrom Sıklığı ve Özelliklerinin Araştırılması
}

\author{
Investigation of Metabolic Syndrome Frequency and Characteristics in Overweight Children
}

${ }^{1}$ Özel Güngören Hastanesi, Neonataloji Birimi, İstanbul,Türkiye

${ }^{2}$ Okmeydanı Eğitim ve Araștırma Hastanesi, İstanbul,Türkiye,
Correspondence:

Akan YAMAN

Özel Güngören Hastanesi,

Neonataloji Birimi, İstanbul,Türkiye e-mail: drayaman80@gmail.com
${ }^{1}$ Akan Yaman, ${ }^{1}$ İbrahim Kandemir, ${ }^{2}$ Fügen Pekün

Fazla kilolu ve obez çocuklarda metabolik sendrom (MS) sıklığının saptanması ve MS bulgularının karşılaştırılması. Çalışmaya Haziran-Aralık 2008 tarihleri arasında İstanbul Okmeydanı Eğitim ve Araştırma Hastanesi Çocuk Sağlığı ve Hastalıkları polikliniğine başvuran sistemik, endokrin veya nörolojik hastalığı olmayan 102 fazla kilolu ve obez vaka alındı. Vakalar MS klinik bulguları, antropometrik ölçümler ve laboratuvar sonuçları (insülin direnci, kan şekeri, 'high density lipoptorein' (HDL) kolesterol (HDL-C), 'low density lipoprotein' (LDL) kolesterol (LDL-C), 'very low density lipoprotein' VLDL kolesterol (VLDL-C), trigliserit, C-reaktif protein (CRP), aspartat transaminaz (AST), alanin transaminaz (ALT), üre ve kreatinin düzeyleri) açısından araştırıldı, aile öyküleri sorgulandı. MS tanısını koymak için modifiye "National Cholesterol Education Program Adult Treatment Panel

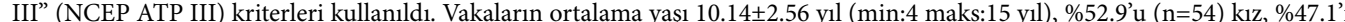
$(\mathrm{n}=48)$ erkek idi. Çalışmaya alınan çocuk ve adolesanların \%28.4'ü (n:29) fazla ağırlıklı ve \%71.6'sı (n:73) obezdi. Obez ve fazla kilolu hastalarda hastalarda MS sıklığı sırasıyla \%50,6 (n:37) ve \%37,9 (n=11) idi. MS(+) olan grupta MS(-) olan gruba kıyasla aile öyküsünde MS olması ( $\mathrm{p}=0,021)$, insülin direnci $(\mathrm{p}<0,001)$, açlık kan şekeri yüksekliği $(\mathrm{p}=0,008)$, akantozis nigrikans saptanması $(\mathrm{p}=0,021)$, hipertansiyon $(\mathrm{p}=0,001)$, bel çevresinde artış $(\mathrm{p}=0,014)$, CRP yüksekliği $(\mathrm{p}=0,048)$, trigliserit yüksekliği $(\mathrm{p}=0,008)$, VLDL-C yüksekliği $(\mathrm{p}=0,002)$ ve HDL-C düşüklüğü $(\mathrm{p}=0,047)$ istatistiksel olarak anlamlıydı. Fazla ağırlıklı hastaların da obez vakalar gibi MS açısından tetkik ve takibi gereklidir. Ülkemizde MS sıklığının tespiti için çok merkezli prospektif çalışmalar gerekmektedir.

Anahtar Kelimeler: Metabolik sendrom, Pediatrik obezite, Fazla kilolu çocuk, NCEP ATP III

\section{Abstract}

To investigate the frequency and characteristics of metabolic syndrome (MS) in overweight and obese children. We included 102 overweight and obese cases without systemic, endocrine, or neurological diseases who applied to Istanbul Okmeydanı Training and Research Hospital Pediatrics Outpatient Clinic in the study. We investigated the patients in terms of MS clinical findings, anthropometric measurements, laboratory results (insulin resistance, blood glucose, 'high-density lipoprotein (HDL) cholesterol (HDL-C), 'low-density lipoprotein' (LDL) cholesterol (LDL-C), 'very low' Density lipoprotein (CLDL) cholesterol (VLDL-C), triglyceride, C-reactive protein (CRP), aspartate transaminase (AST), alanine transaminase (ALT), urea and creatinine levels), and family histories. Modified "National Cholesterol Education Program Adult Treatment Panel III" (NCEP ATP III) criteria were used to diagnose MS. The mean age of the cases was $10.14 \pm 2.56$ years (min:4 max:15 years), $52.9 \%(\mathrm{n}=54)$ were female, $47.1 \%(\mathrm{n}=48)$ were male. Of the children and adolescents included in the study, $28.4 \%$ (n: 29) were overweight and 71.6\% (n: 73) were obese. The prevalence of MS in obese and overweight patients was $50.6 \%(\mathrm{n}: 37)$ and $37.9 \%(\mathrm{n}=11)$, respectively. In the MS(+) group compared to the MS(-) group, having MS in the family history ( $\mathrm{p}=0.021)$, insulin resistance $(\mathrm{p}<0.001)$, high fasting blood glucose $(\mathrm{p}=0.008)$, acanthosis nigricans $(\mathrm{p}=0.021)$, hypertension $(\mathrm{p}=0.001)$, increase in waist circumference $(\mathrm{p}=0.014)$, high CRP $(\mathrm{p}=0.048)$, high triglyceride $(\mathrm{p}=0.008)$, high VLDL-C $(\mathrm{p}=0.002)$ and low HDL-C $(\mathrm{p}=0.047))$ was statistically significant. Examination and follow-up of overweight patients in terms of Metabolic syndrome is required, just like obese patients. Multicenter prospective studies are needed to determine the frequency of MS in our country.

Keywords: Metabolic syndrome, Pediatric obesity, Pediatric overweight, NCEP ATP III

Received 15.11.2021 Accepted 07.02.2022 Online published 09.02.2022 


\section{Giriş}

Metabolik sendrom; dünyada sıklığı giderek artan önemli bir morbitide ve mortalite nedeni olup ilk zamanlar erişkinlerin sorunu olarak bilinirken artık çocukluk ve adolesan dönemde de çok s1k görülmekte erişkin dönemde en s1k ölüm nedeni olan kardiyovasküler hastalıkların zeminini oluşturmaktadır $(1,2)$.

Metabolik sendrom (MS); insülin-rezistans veya sendrom-X olarak da adlandırılmaktadır (3). Metabolik sendromun özünde hücresel metabolizma bozukluğu ve buna bağl1 insülin direnci olarak göze çarpmaktadır (4). MS gelişen bireylerde santral obezite, hipertansiyon, kan trigliserit seviyelerinde artıș, HDL-C düşüklüğü ve açlık kan şekerinde artış gibi ciddi kardiyovasküler risk faktörlerinin bir araya geldiği klinik bir tablodur $(3,5)$. Aterojenik dislipidemiye bağlı olarak ileri yaşlarda aterosklerotik kardiyovasküler hastalık ortaya çıkar (6).

Son y1llarda MS s1klığı pediatrik ve adolesan yaş gruplarında artış göstermektedir (1). Ancak metabolik sendrom sadece obezlerde değil, fazla kilolu çocuklarda da görülebilmektedir. $\mathrm{Bu}$ çalışmamızın amacı obezlerde ve kilolu çocuklarda metabolik sendrom sıklığının belirlenmesi ve MS faktörlerinin karşılaştırılmasıdır.

\section{Gereç ve Yöntem}

Çalışma Mart 2007-Aralık 2008 tarihleri arasında prospektif ve kesitsel olarak yapıldı. Çalışmaya hastanemiz (Okmeydanı Eğitim ve Araştırma Hastanesi) pediatri polikliniğine başvuran yaşları 4 - 15 yaş arasında değișen 102 fazla kilolu ve obezite tanisı konulan hasta çalışmaya alındı. Kronik hastalığı olan, kilo alımına neden olabilecek ilaç (steroid kullanımı gibi) ve hastalığı (prader willi sendromu gibi) olan vakalar çalışmaya alınmadı. Görevlendirilmiş bir hemşire tarafından ağırlık ve boy ölçümleri, ve göbek hizasından mezura ile de bel çevresi ölçümleri yapıldı. Hemşire tarafindan civalı sfigmomanometreyle uygun boyutta manşon kullanılarak sistolik ve diastolik kan basınçları ölçüldü. birinci ses sistolik basınç olarak kaydedildi., seslerin kaybolması da (5. Faz) diastolik basınç olarak kaydedildi. Tansiyon ölçümünden 30 dakika öncesinde kafeinli gıda tüketmemesi koşuluyla 15 dakika sessiz bir ortamda dinlendirildi ve ölçümler 5 dakika aralıklarla en az 2 defa yapıldı. İki ölçüm arasinda $5 \mathrm{~mm} \mathrm{Hg}$ 'dan fazla fark varsa ilave ölçümler yapıldı. Ölçümlerin ortalaması alınd. Vücut kitle indeksi (VKI) ağırlık(kilogram) / boy(metre) ${ }^{2}$ olarak hesapland1. Bel çevresi ve vücut kitle indeksi değerlendirilmesinde Günöz VKİ persentil eğrileri kullanıldı (7). Arteryel tansiyon persentilleri değerlendirilmesinde Türk hipertansiyon persentil eğrileri kullanıldı (8). Hastalardan bir gece açlık sonrasında sabah 08:00'de tahlil için kan numuneleri alındı. Serumda total kolesterol "kolesterol esteraz" metoduyla, trigliserit, HDL kolesterol "enzimatik kalorimetrik" metodla, LDL kolesterol, VLDL kolesterol "friedewal formülü"yle, açlık kan şekeri "hekzokinaz metoduyla", karaciğer enzimleri (AST, ALT) "enzimatik kalorimetrik" metodla çalıştırıldı. İnsülin düzeyleri "elektrokemilüninesans Immünoassay (ECLIA)" yöntemiyle çalışıldı. Üre UV metod üreaz yöntemiyle, kreatinin değerleri colorometricassay jaffe metoduyla, C- reaktif protein düzeyi ise nefelometrik olarak yapild1.

İnsülin direnci (HOMA-IR) açlık kan şekeri $(\mathrm{mg} / \mathrm{dL}) \quad \mathrm{x}$ açlik insülin $(\mu \mathrm{u} / \mathrm{ml}) / 405$ formülüyle hesaplandı ve 2,7'nin üstünde saptanan sonuçlar insülin direnci kabul edildi (9).

MS tanıs1 için geliştirilen NCEP ATP III kriterlerine göre kadınlarda $88 \mathrm{~cm}$ erkeklerde $102 \mathrm{~cm}$ ve üstü bel çevresi, $150 \mathrm{mg} / \mathrm{dL}$ ve üstü trigliserit seviyesi (veya hipertrigliseridemi nedeniyle tedavi), HDL-C'nin kadınlarda $<50$ $\mathrm{mg} / \mathrm{dl}$, erkeklerde $40 \mathrm{mg} / \mathrm{dl}$ altında veya bunun için tedavi alıyor olması, hipertansiyon $(\geq 130 \mathrm{~mm} \mathrm{Hg}$ sistolik, veya $\geq 85 \mathrm{~mm} \mathrm{Hg}$ diyastolik) veya hipertansiyon öyküsü nedeniyle anti hipertansif tedavi alıyor olmak, ve açlik kan glikozunun $\geq 100 \mathrm{mg} / \mathrm{dl}$ veya şeker yüksekliği nedeniyle tedavi altında olmak kriterlerinden 3 ünün sağlanması durumunda metabolik sendrom tanıs1 konmaktadır (6). Çocuklar için kriterler konusunda fikir birliği yoktur. $\mathrm{Bu}$ çalışmamızda modifiye edilmiş NCEP ATP 
III kriterleri kullanılarak metabolik sendrom tanıs1 konuldu (10). $\mathrm{Bu}$ kriterlere göre trigliserit düzeyi $>95$ persentil, HDL-C $<5$ persentil, sistolik veya diastolik tansiyon $>95$ persentil ve bozulmuş glikoz toleransı kriterlerinden en az 3 ünün karşılanması gerekmektedir (10). Çalışmaya alınan olgularda metabolik sendrom tanisı modifiye edilmiş NCEP ATP III kriterleri ile konuldu $(6,10)$.

Etik kurul onayı 2007 yılında Okmeydanı Eğitim ve Araştırma Hastanesi etik kurulundan, akademik kuruldan geçerek uzmanlık tezi onayı olarak alındı. Çalışma 2009 yılında Okmeydanı Eğitim ve Araştırma Hastanesinde uzmanlı tezi olarak hazırlanmıştır. Daha sonra bu çalışma güncel verilerle 2021 yılında makale olarak hazırlanmıştır.

\section{İstatistiksel İncelemeler}

İstatistiksel işlemler için NCSS 2007\&PASS 2008 Statistical Software (Utah, USA) paket programı kullanıldı. İstatistiksel verilerde tanımlayıcı özellikler ortalama ve standart sapma şeklinde verildi. Birbirlerinden bağımız iki grup arasında sürekli değişkenlerin karşılaştırılmasında dağ 1 lım şekline göre Student's t test ve Mann-Whitney u testleri, kategorik değişkenlerin karşılaştırılmasında ise ki-kare testi kullanıldı. İstatistiksel olarak $\mathrm{p}<0,05$ anlamlı kabul edildi.

\section{Bulgular}

Çalışmaya alınan 4-15 yaş arasında 102 çocuk ve adolesanın $(\% 52,9$ 'u $(\mathrm{n}=54) \mathrm{k1z}, \% 47,1$ 'i $(n=48)$ erkek) ortalama yaşları $10,14 \pm 2,56$ y1 saptand1. Boyları ortalama 143,94 $\pm 13,53 \mathrm{~cm}$ (minimum 108,5 maksimum 173), ağırlıkları $59,21 \pm 19,23 \quad \mathrm{~kg} \quad$ (minimum:24,5 maksimum:125) saptandı. Yaşa göre VKİ eğrilerine göre vakaların \%71,6'sının $(n=73)$ obez, \%28,4'ünün $(\mathrm{n}=29)$ fazla ağırlıklı olduğu saptand1. Obez ve fazla ağırlıklı hastalarda MS sıklığı sirasıyla \%50,6 (n:37) ve $\% 37,9 \quad(n=11) \quad$ saptand1. MS siklığ 1 obezlerde istatistiksel olarak anlamlı şekilde yüksekti $(p=0,026)$. Cinsiyet açısından MS sıklığında istatistiksel olarak anlamlı bir fark saptanmadı (tablo 1).

MS saptanan ve saptanmayan hastaların karşılaştırmalı demografik özellikleri ve tansiyon persentillerinin istatistiksel sonuçları tablo 1'de verilmiştir.

Tablo 1. Hastaların demografik özelliklerinin ve tansiyon persentillerinin MS görülme durumuna göre karşılaştırılması

\begin{tabular}{llll}
\hline & MS $(+)(\mathbf{n}=\mathbf{4 8})$ & MS(-) $(\mathbf{n}=\mathbf{5 4})$ & $\mathbf{p}$ \\
\hline Cinsiyet, $\mathbf{n}(\%)$ & K1z: $24(\% 50)$ & Kı: $30(\% 56)$ & $\mathrm{P}=0,575(*)$ \\
& Erkek: $24(\% 50)$ & Erkek: $24(\% 44)$ & \\
Yaş (yıl) & $10,42 \pm 2,54$ & $9,9 \pm 2,58$ & $\mathrm{P}=0,307(* *)$ \\
\hline *: Ki-kare testi, **: Student's t test & &
\end{tabular}

Vakaların \%35,3'ünde $(\mathrm{n}=36)$ ailesinde astım, $\% 25,5$ 'inde $(n=26)$ alerji, \%58,8'inde $(n=60)$ obezite, $\% 9,8$ 'inde $(n=10)$ gebelikte maternal diyabet öyküsü; \%19,6(n=20)'sında Diabetes mellitus Tip 1, \%46,1(n=47)'inde Diabetes mellitus Tip 2, \%36,3'ünde $(\mathrm{n}=37)$ ailede $\mathrm{MS}$, $\% 72,5$ 'inde $(\mathrm{n}=74)$ hipertansiyon,
$\% 19,6$ 'sinda $\quad(n=20) \quad$ stroke (inme), ve \%79,4'ünde $(\mathrm{n}=81)$ sigara içen birey mevcuttu. Hastaların aile öyküsünün metabolik sendrom görülme durumuna göre istatistiksel karşılaştırılması tablo 2 de verilmiştir. 
MS saptanan grupta bel çevresi $(p=0,014)$, yaşa göre kan basıncının $>90$ persentil olma durumu $(\mathrm{p}=0,001)$ ve vücut kitle endeksi persentillerine göre obez grupta olma durumları $\quad(p=0,026) \quad$ istatistiksel olarak yüksek saptand1. Hastaların bel çevreleri ve tansiyon persentillerinin metabolik sendrom görülme durumuna göre istatistiksel karşılaştırılması tablo 5'te verilmiştir

Tablo 5. Hastaların bel çevreleri ve tansiyon persentillerinin MS görülme durumuna göre karşılaştırılması

\begin{tabular}{|c|c|c|c|}
\hline & $\operatorname{MS}(+)(n=48)$ & MS(-)(n=54) & $\mathbf{P}$ \\
\hline Bel çevresi $(\mathrm{cm})$ & $92,10 \pm 13,33$ & $86,01 \pm 11,32$ & $0,014(*)$ \\
\hline $\begin{array}{l}\text { Yaşa göre kan basıncı } \\
>90 \text { persentil, } n(\%)\end{array}$ & $43(\% 89,6)$ & $12(\% 22,2)$ & $0,001(* *)$ \\
\hline $\begin{array}{l}\text { VKİ eğrisine göre } \\
\text { obez/fazla ağırlıklı, n } \\
(\%)\end{array}$ & $\begin{array}{c}37(\% 77,1) \text { obez } \\
11(\% 22,9) \text { fazla ağırlıklı }\end{array}$ & $\begin{array}{c}36(\% 66,7) \text { obez } \\
18(\% 33,3) \text { fazla ağırlıklı }\end{array}$ & $0,026(* *)$ \\
\hline
\end{tabular}

*: Student's t test, **: Ki-kare testi

\section{Tartışma}

Çalışmamızda obez ve fazla kilolu hastalarda MS sıklı̆̆ 1 sirasiyla \%50,6 (n:37) ve \%37,9 $(\mathrm{n}=11)$ olup literatüre göre yüksek saptand. Litvanyada yapılan bir araştırmada 10-17 yaş arası obez ve fazla ağırlıklı çocuklarda MS sıklığ1 \%21,3 olarak bildirilmiştir (11). Gauthier ve arkadaşlarının (12) Michigan'da yaşayan çocuklarda obezite prevelansını saptamak amaciyla yapmış oldukları çalışmada; 4 ve 17 yaş arasında erkeklerin ve kızların sirasiyla \%54'ü ve \%46's1 obez ve fazla ağırlıklı saptanmıştır. Bu çalışmada obez çocuk ve adolesanlarda kız ve erkek oranları sirasiyla \%56,16 (n=40) ve \%43,84 (n=33) idi, cinsiyet açısından kızlar ile erkeklerin VKI düzeyleri açısından istatistiksel olarak anlamlı fark yoktu $(\mathrm{p}=0,575)$. MS prevelans1 çocuk ve adolesan yaş grubunda artmaktadır (1). ABD'de bütün adolesanlarda 2000-2010 arasında \%10'dan fazladır (13). Amerika Birleşik Devletleri'nde fazla kilolu çocuklar arasında metabolik sendrom siklığı \%30'a varan oranda olduğu bildirilmektedir (14). Bir meta-analiz çalışmasında çocuklarda metabolik sendromun ortalama prevalans1 genel popülasyonlarda $\% \quad 3,3$ fazla kilolu çocuklarda \%11,9 ve obez çocuklarda \%29,2 olarak belirtilmiştir. Obez veya fazla kilolu olmayan popülasyonlar için aralık $\% \quad 0-1$ olarak verilmiştir (15). Kuveyt'te yapılan bir çalışmada obez ergenlerde metabolik sendrom sıklığı \%14.4, Kanada'da çocuk ve adolesanlarda yapılan bir araştırmada (genel popülasyon) Amerikan yerlileri kökenli halkta metabolik sendrom prevelansı \%19 olarak saptanmıştır (16, 17). Genel popülasyonda adolesanlarda MS prevalansını \%38,9 kadar yüksek bildiren çalışmalar da mevcuttur (18).

$\mathrm{Bu}$ çalışmamızda MS görülme sıklığında cinsiyet açısından istatistiksel bir fark saptanmadi. Biobank Standardization and Harmonization for Research Excellence in the European Union (BIOSHARE-EU) tarafindan hazırlanan bir raporda, obezlerde metabolik sendrom prevalansı kız çocuklarda \%24-65 arasinda ve erkeklerde \%43-78 arasinda değişmektedir (19). Başka bir çalışmada da kilo vermek isteyen obez adolesanlar arasinda erkeklerde \%27 k1zlarda \%19 oranında görüldüğ̈ ve bu oranların istatistiksel olarak farklı olmadığ 1 bildirilmiştir (20). Yine bir çalışmada kızlarda ve erkeklerde istatistiksel olarak benzer MS prevalansı olduğu bildirilmiştir (21).

Bir çalışmada annede obezite ve gestasyonel diabetes mellitus görülmesinin çocuklarında MS görülme ihtimalini artırdığ savunulmuştur (22). Yine başka bir çalışmada gestasyonel diabet tanilı annelerin çocuklarında metabolik sendrom görülme ihtimalinin 2 kat fazla olduğu bildirilmiştir (23). Ancak çalışmamızda maternal obezite ve gestasyonel diabetes mellitus saptanan grupta, saptanmayan gruba kıyasla MS görülme açısından istatistiksel olarak anlamlı fark saptanmadi.

MS genetik yatkınlık açısından erişkinler üzerinde araştırmalarda bir çalışmada ailede 
hipertansiyon, stroke ve diabetes mellitus görülmesinin MS prevalansını istatistiksel olarak etkilediği (24), başka bir çalışmada genetik olmayan ailevi faktörlerin de MS açısından rolü olabileceği savunulmuştur (25). Çocuklar üzerinde yapılan bir çalışmada ailede hipertansiyon öyküsü olan öğrencilerin dislipidemi, HT ve obezite açısından riskli oldukları savunulmuştur (26). Başka bir çalışmada ebeveynlerinden herhangi birisinde MS olan ailelerin çocuklarının olmayanlara göre MS açısından 4,8 kat daha fazla risk altında olduğu bildirilmiştir (27). Ebeveynlerden birisinde MS saptanmas1 durumunda çocuklarında da MS gelişme ihtimali daha yüksek olduğu belirtilmekte ve MS açısından taranmaları önerilmektedir (28). Bizim çalışmamızda aile öyküsünde MS saptanan çocuk ve adolesanlarda MS görülme ihtimali istatistiksel olarak yüksek saptandı. Ancak ailede astım, allerjik hastalıklar, obezite, GDM, Tip 1 DM, Tip 2 DM, koroner kalp hastalığ 1 , hipertansiyon, inme ve sigara kullanma öyküsü ile MS görülme açısından istatistiksel olarak anlamlı fark saptanmadı.

MS insülin direncine sekonder ortaya çıkan bir klinik tablo olduğu düşünülmektedir (5, 28). Türk çocuklarında yapılan bir çalışmada obez çocukların \%10.8'inde glukoz intolerans1 olduğu görülmüş, \%74.7'sinde de hiperinsülinizm saptanmıştır (29). Kuveyt'te obez ergenlerde yapılan bir çalışmada insülin direnci \% 56.7 (16), 6-8 yaş arası Brezilyalı obez çocuklarda \% 84.5 (30), ve İspanyol 418 yaş arası çocuklarda \%35.8 bulunmuştur (31). Bir çalışmada glukoz intolerans sıklığ 1 obez çocuklarda ve adolesanlarda sirasıyla \% 25 ve \% 21 olarak (32) bildirilmiştir. Hindistan'da yapılan bir çalışmada da genel popülasyonda 6-16 yaş arası çocukların $\% 28.2$ 'sinin obez veya fazla ağırlıklı olduğu saptanmış, MS sıklığı (genel popülasyonda) \%21,8 olarak bildirilmiştir. Aynı yayın MS saptanan hastalarda MS saptanmayanlara göre insülin direncinin daha sik görüldüğünü savunmuştur (33). Litvanya'da ise obez ve fazla kilolu çocukların \%6,9'unda bozulmuş açlık glikozu ve \%4,5'inde bozulmuş glikoz toleransı saptanmıștır (11). Çalıșmamızda (fazla kilolu ve obez) olgularm \%68,6'inde, MS(+) olan olgularda ise $\% 87,5^{\prime}$ inde insülin direnci saptand. $\mathrm{MS}(+)$ vakalarda insülin direnci MS(-) olanlara kiyasla istatistiksel olarak anlamlı şekilde yüksek saptandı. Ayrıca MS(+) vakaların açlık kan şekeri MS() olanlara göre ortalama $5,84 \mathrm{mg} / \mathrm{dl}$ daha yüksekti.

Strialar ve akantozis nigrikans MS cilt bulgularındandır. Akantozis nigrikans saptanan hastalarda tip 2 diyabet riski artmıştır (34). Bir çalışmada akantozis nigrikans bulgusunun insülin direnci ve tip 2 diyabet ile ilişkili olduğu bildirilmiş̧tir (35). Bir çalışmada akantozis nigrikans MS saptanan hastaların \%46,4'ünde görüldüğü bildrilmiştir (33). Çalışmamızda akantozis nigrikans görülme oranı MS (+) hastalarda MS(-) olgulara kiyasla istatistiksel olarak anlamlı şekilde fazla saptand 1 ancak strialar açısından anlamlı fark bulunmadi. Ancak obez çocukların ve ergenlerin neredeyse \% 90'inda en az bir metabolik sendrom bulgusu olduğu bildirilmiştir (14).

Çalışmalarda obez adolesanlarda erişkin dönemde hipertansiyon saptanma ihtimalinin, obez olmayanlara k1yasla 8,5 kat arttı̆̆ bildirilmiştir (19, 36). Başka bir çalışmada pediatrik yaş grubunda obez çocukların \%25,7'sinde hipertansiyon olduğu bildirilmiştir (37). Çalışmamızda yaşa göre arteriyel tansiyon eğrileri $\mathrm{MS}(+)$ hastalarda istatistiksel olarak anlamlı şekilde yüksek saptand.

Brezilya'da 6-8 yaş arası obez çocukların \% 84.9'unda bel çevresi artış1 saptandığ bildirilmiştir (30). Başka bir çalışmada da obez çocuklarda abdominal obezite \% 88.6 oranında saptanmıştır (37). Üçüncü Ulusal Sağlık ve Beslenme Araştırması (National Health and Nutrition Examination Survey NHANES)'na göre Cruz ve Goran'ın (38) önerdiği kriterler göz önüne alındığında çalışmamızda olgularımızın ortalama bel çevresi $88,902 \pm 12,74 \mathrm{~cm}$ idi. çalışmamızda iki grup bel çevresi açısından karşılaş̧ırıldığında MS (+) hastaların bel çevresinin istatistiksel olarak daha fazla olduğu saptandi.

MS patogenezinde hafif derecede sistemik bir enflamatuar yanıta yol açar (39) ve bu durumun koroner arter hastalığı riskinde artışa yol açtığ1 düşünülmektedir $(40,41)$. Genel toplumsal bir çalışmada C-reaktif protein ile total kolesterol, trigliserit, vücut kitle indeksi 
ve kan glikoz düzeyleri arasında ilişki olduğu bildirilmiștir (42). Başka bir çalıșmada Creaktif protein ile vücut kitle indeksi, insülin direnci, açlık insülin düzeyleri arasında korelasyon olduğu bildirilmiştir (43). Pediatrik yaş grubunda yapılmış olan bir çalışmada vücut kitle indeksinde görülen +1 standart sapmalık artışın C-reaktif protein düzeylerinde $\% 50$ kadar artı̧̧la ilişkili olduğu savunulmuştur (44). Bizim çalışmamızda da $\mathrm{MS}(+)$ hastalarda C-reaktif protein MS(-) olgulara kıyasla istatistiksel olarak anlamlı şekilde yüksek saptandi.

Bir çalışmada 7-11 yaş çocuklarda vücut yağ oraniyla serum TG ve TC/HDL-C oran arasında pozitif korelasyon olduğu savunulmuştur (45). Pediatrik yaş grubunda yapılan başka bir çalışmada da obezite ile total kolesterol, trigliserit, VLDL-C, LDL-C (pozitif korelasyon) ve HDL-C düzeyleri (negatif korelasyon) korele olduğu savunulmuştur (46). Brezilyalı çocuklarda yapılan başka bir çalışmada da vücut kitle

\section{KAYNAKLAR}

1. NCD Risk Factor Collaboration (NCD-RisC). Worldwide trends in body-mass index, underweight, overweight, and obesity from 1975 to 2016: a pooled analysis of 2416 population-based measurement studies in 128.9 million children, adolescents, and adults. Lancet. 2017;390:2627-42.

2. Berenson GS, Srinivasan SR, Bao W, Newman WP 3rd, Tracy RE, Wattigney WA. Association between multiple cardiovascular risk factors and atherosclerosis in children and young adults. The Bogalusa Heart Study. $N$ Engl J Med. 1998;338:1650-6.

3. Reaven G. The metabolic syndrome or the insulin resistance syndrome? Different names, different concepts, and different goals. Endocrinol Metab Clin North Am. 2004 ;33:283-303.

4. Shulman GI. Ectopic fat in insulin resistance, dyslipidemia, and cardiometabolic disease. $\mathrm{N}$ Engl J Med. 2014;371:1131-41. doi: 10.1056/NEJMra1011035. Erratum in: $N$ Engl J Med. $2014 ; 371: 2241$.

5. Reaven GM. Banting lecture 1988. Role of insulin resistance in human disease. Diabetes. 1988;37:1595-607.

6. Grundy SM, Cleeman JI, Daniels SR, Donato KA, Eckel RH, Franklin BA, Gordon DJ, Krauss RM, Savage PJ, Smith SC Jr, Spertus JA, Costa F; American Heart Association; indeksi ve bel çevresinin, insülin direnci ve TG düzeyleriyle anlamlı bir korelasyona sahip olduğu bildirilmiştir (30). Çalışmamızda MS saptanan olgularda trigliserit, VLDL-C ve açlık glukoz düzeyleri istatistiksel olarak daha yüksek ve HDL-C düzeyi istatistiksel olarak daha düşük saptand1. Ancak trigliserit, AST, $\mathrm{ALT}$, serum üre ve kreatinin açısından $\mathrm{MS}(+)$ hastalar ile MS(-) hastalar arasında istatistiksel olarak anlamlı bir fark saptanmad1.

\section{Sonuç}

Yalnızca fazla kilolu ve obez vakaların dahil edildiği çalışmamızda obez vakalarda MS görülme sıklı̆g fazla kilolu olanlara kıyasla yüksek saptandı. Ancak vaka grubumuzdaki fazla kilolu olgularda MS görülme sıklığı literatürdeki verilere kıyasla yüksek saptanması nedeniyle fazla ağırlıklı olan çocukların da MS görülme ihtimali açısından takip edilmesi gerektiğini düşünüyoruz. Ülkemizde MS sıklığının tespiti için çok merkezli prospektif çalışmalar gerekmektedir.

National Heart, Lung, and Blood Institute. Diagnosis and management of the metabolic syndrome: an American Heart Association/National Heart, Lung, and Blood Institute Scientific Statement. Circulation. 2005; 112:2735-52. doi: 10.1161/CIRCULATIONAHA.105.169404. Epub 2005 Sep 12. Erratum in: Circulation. 2005;112:e297. Erratum in: Circulation. 2005;112:e298.

7. Günöz, H., Öcal, G., Yordam, N., \& Kurtoğlu, S. (2003). Pediatrik Endokrinoloji. 1. basım. Pediatric Endokrinoloji ve Oksoloji Derneği Yayınları, Kalkan matbaacılı, Ankara, 768-769.

8. Neyzi O, Ertuğrul T, Pediatri 1. 3. bask1. Nobel Tip Kitabevleri, Ankara, 2002. 91-96.

9. Arslan, M., Atmaca, A., Ayvaz, G., Başkal, N., Beyhan, Z., Bolu, E., ... \& Yilmaz, M. Metabolik sendrom klavuzu. Türkiye Endokrinoloji ve Metabolizma Derneği. 2009.

10. Weiss R, Dziura J, Burgert TS, Tamborlane WV, Taksali SE, Yeckel CW, Allen K, Lopes M, Savoye M, Morrison J, Sherwin RS, Caprio S. Obesity and the metabolic syndrome in children and adolescents. $N$ Engl $J$ Med. 2004;350:2362-74.

11. Smetanina N, Valickas R, Vitkauskiene A, Albertsson-Wikland K, Verkauskienè R. Prevalence of Metabolic Syndrome and 
Impaired Glucose Metabolism among 10- to 17-Year-Old Overweight and Obese Lithuanian Children and Adolescents. Obes Facts. 2021;14:271-82.

12. Gauthier BM, Hickner JM, Noel MM. High prevalence of overweight children in Michigan primary care practices. An UPRNet study. Upper Peninsula Research Network. J Fam Pract. 2000;49:73-6.

13. Pucci G, Alcidi R, Tap L, Battista F, MattaceRaso F, Schillaci G. Sex- and gender-related prevalence, cardiovascular risk and therapeutic approach in metabolic syndrome: A review of the literature. Pharmacol Res. 2017;120:34-42.

14. Cook S, Weitzman M, Auinger P, Nguyen M, Dietz WH. Prevalence of a metabolic syndrome phenotype in adolescents: findings from the third National Health and Nutrition Examination Survey, 1988-1994. Arch Pediatr Adolesc Med. 2003;157:821-7.

15. Friend A, Craig L, Turner S. The prevalence of metabolic syndrome in children: a systematic review of the literature. Metab Syndr Relat Disord. 2013 Apr;11(2):71-80.

16. Davidsson L, Alkhabbaz E, Vijayan V, Alhubail A, Shaltout A, Alkandari H. Intermediate hyperglycaemia, insulin resistance and metabolic syndrome among obese Arab children (12-17 years old) in Kuwait. Prim Care Diabetes. 2021 ;15:191-3.

17. Retnakaran R, Zinman B, Connelly PW, Harris SB, Hanley AJ. Nontraditional cardiovascular risk factors in pediatric metabolic syndrome. J Pediatr. 2006 ;148:17682.

18. Al-Hamad D, Raman V. Metabolic syndrome in children and adolescents. Transl Pediatr. 2017;6:397-407.

19. van Vliet-Ostaptchouk JV, Nuotio ML, Slagter SN, Doiron D, Fischer K, Foco L, Gaye A, Gögele M, Heier M, Hiekkalinna T, Joensuu A, Newby C, Pang C, Partinen E, Reischl E, Schwienbacher C, Tammesoo ML, Swertz MA, Burton P, Ferretti V, Fortier I, Giepmans L, Harris JR, Hillege HL, Holmen J, Jula A, Kootstra-Ros JE, Kvaløy K, Holmen TL, Männistö S, Metspalu A, Midthjell K, Murtagh MJ, Peters A, Pramstaller PP, Saaristo T, Salomaa V, Stolk RP, Uusitupa M, van der Harst $P$, van der Klauw MM, Waldenberger M, Perola M, Wolffenbuttel $\mathrm{BH}$. The prevalence of metabolic syndrome and metabolically healthy obesity in Europe: a collaborative analysis of ten large cohort studies. BMC Endocr Disord. 2014;14:9.

20. Barstad LH, Júlíusson PB, Johnson LK, Hertel JK, Lekhal S, Hjelmesæth J. Gender-related differences in cardiometabolic risk factors and lifestyle behaviors in treatment-seeking adolescents with severe obesity. BMC Pediatr. 2018;18:61.

21. Calcaterra V, Larizza D, De Silvestri A, Albertini R, Vinci F, Regalbuto C, Dobbiani G, Montalbano C, Pelizzo G, Cena H. Genderbased differences in the clustering of metabolic syndrome factors in children and adolescents. J Pediatr Endocrinol Metab. 2020;33:279-88.

22. Boney CM, Verma A, Tucker R, Vohr BR. Metabolic syndrome in childhood: association with birth weight, maternal obesity, and gestational diabetes mellitus. Pediatrics. 2005; 115:e290-6.

23. Pathirana MM, Lassi ZS, Ali A, Arstall MA, Roberts CT, Andraweera PH. Association between metabolic syndrome and gestational diabetes mellitus in women and their children: a systematic review and meta-analysis. Endocrine. 2021;71:310-20.

24. Paek KW, Chun KH, Lee KW. Relationship between metabolic syndrome and familial history of hypertension/stroke, diabetes, and cardiovascular disease. J Korean Med Sci. 2006;21:701-8.

25. Liese AD, Mayer-Davis EJ, Tyroler HA, Davis CE, Keil U, Schmidt MI, Brancati FL, Heiss G. Familial components of the multiple metabolic syndrome: the ARIC study. Diabetologia. 1997;40:963-70. doi: 10.1007/s001250050775. Erratum in: Diabetologia $1998 ; 41: 608$.

26. Williams JE, Paton CC, Siegler IC, Eigenbrodt ML, Nieto FJ, Tyroler HA. Anger proneness predicts coronary heart disease risk: prospective analysis from the atherosclerosis risk in communities (ARIC) study. Circulation. 2000;101:2034-9.

27. Park HS, Park JY, Cho SI. Familial aggregation of the metabolic syndrome in Korean families with adolescents. Atherosclerosis. 2006;186:215-21.

28. Magge SN, Goodman E, Armstrong SC; COMMITTEE ON NUTRITION; SECTION ON ENDOCRINOLOGY; SECTION ON OBESITY. The Metabolic Syndrome in Children and Adolescents: Shifting the Focus to Cardiometabolic Risk Factor Clustering. Pediatrics. 2017;140:e20171603.

29. Adryaman, P., Ocal, G., Berberoğlu, M., Aycan, Z., Evliyaoğlu, O., \& Çetinkaya, E. (2002, September). Hyperinsulinism and dyslipidemia in glucose tolerant and intolerant obese children. In 41 st Annual Meeting of the European Society for Pediatric Endocrinology (pp. 25-28).

30. Sentalin PBR, Pinheiro AO, Oliveira RR, Zângaro RA, Campos LA, Baltatu OC. Obesity and metabolic syndrome in children in Brazil: The challenge of lifestyle change. Medicine (Baltimore). 2019;98:e15666.

31. Tresaco B, Bueno G, Moreno LA, Garagorri $\mathrm{JM}$, Bueno M. Insulin resistance and impaired glucose tolerance in obese children and adolescents. J Physiol Biochem. 2003;59:21723.

32. Saltiel AR, Kahn CR. Insulin signalling and the regulation of glucose and lipid metabolism. Nature. 2001;414:799-806.

33. Das RR, Mangaraj M, Panigrahi SK, Satapathy AK, Mahapatro S, Ray PS. Metabolic Syndrome and Insulin Resistance in 
Schoolchildren From a Developing Country. Front Nutr. 2020;7:31.

34. Ten S, Maclaren N. Insulin resistance syndrome in children. $J$ Clin Endocrinol Metab. 2004;89:2526-39.

35. Fu JF, Liang L, Dong GP, Jiang YJ, Zou CC. [Obese children with benign acanthosis nigricans and insulin resistance: analysis of 19 cases]. Zhonghua Er Ke Za Zhi. 2004 ;42:9179. Chinese.

36. Bray GA. Complications of obesity. Ann Intern Med. 1985;103:1052-62.

37. Jmal L, Jmal A, Abdennebi M, Feki M, Boukthir S. Prevalence of metabolic syndrome in Tunisian overweight and obese children. Tunis Med. 2019 ;97:133-39.

38. Cruz ML, Goran MI. The metabolic syndrome in children and adolescents. Curr Diab Rep. 2004;4:53-62.

39. DeBoer MD. Assessing and Managing the Metabolic Syndrome in Children and Adolescents. Nutrients. 2019;11:1788.

40. Hansen BC. The metabolic syndrome X. Ann N Y Acad Sci. 1999;892:1-24.

41. Genoni G, Menegon V, Secco GG, Sonzini M, Martelli M, Castagno M, Ricotti R, Monzani A, Aronici M, Grossini E, Di Mario C, Bona G, Bellone S, Prodam F. Insulin resistance, serum uric acid and metabolic syndrome are linked to cardiovascular dysfunction in pediatric obesity. Int J Cardiol. 2017;249:36671.

42. Fröhlich M, Imhof A, Berg G, Hutchinson WL, Pepys MB, Boeing H, Muche R, Brenner $\mathrm{H}$, Koenig W. Association between C-reactive protein and features of the metabolic syndrome: a population-based study. Diabetes Care. 2000;23:1835-9.

43. Festa A, D'Agostino R Jr, Howard G, Mykkänen L, Tracy RP, Haffner SM. Chronic subclinical inflammation as part of the insulin resistance syndrome: the Insulin Resistance Atherosclerosis Study (IRAS). Circulation. 2000;102:42-7.

44. Lambert M, Delvin EE, Paradis G, O'Loughlin J, Hanley JA, Levy E. C-reactive protein and features of the metabolic syndrome in a population-based sample of children and adolescents. Clin Chem. 2004 ;50:1762-8

45. Gutin B, Owens S, Treiber F, Islam S, Karp W, Slavens G. Weight-independent cardiovascular fitness and coronary risk factors. Arch Pediatr Adolesc Med. 1997 ;151:462-5.

46. Wattigney WA, Harsha DW, Srinivasan SR, Webber LS, Berenson GS. Increasing impact of obesity on serum lipids and lipoproteins in young adults. The Bogalusa Heart Study. Arch Intern Med. 1991;151:2017-22. 